\title{
Rise of intercultural Biblical exegesis in Africa
}

\author{
Jean-Claude Loba-Mkole ${ }^{1}$ \\ Hekima College/UBS \\ Nairobi, Kenya
}

\begin{abstract}
This article traces the rise and development of intercultural Biblical exegesis in Africa, especially with regard to New Testament interpretations. Different trends of Biblical exegesis practiced in Africa are explored, whereafter the different phases of intercultural exegesis are discussed. The focus falls on inculturation hermeneutic as an important method of interpreting the Bible in an African context. The different proponents of this method are discussed and differences in approach are noted and appraised as a healthy tension.
\end{abstract}

\section{INTRODUCTION}

This study intends to document the rise and development of intercultural Biblical exegesis in Africa, especially with regard to New Testament interpretations. It argues that this new exegetical tool was launched in 1996, when Justin Ukpong published an article introducing and applying the method of inculturation Biblical hermeneutic. In 1998 J B Matand, with no reference to Ukpong, embraced this method, which through the books of C N A Cilumba and U C Manus, published respectively in 2001 and 2003, evolved into intercultural Biblical exegesis/hermeneutic. I attempted to enhance these efforts further in 2005, not only by using intercultural Biblical exegesis, but also by viewing it as intercultural mediations. The first section of this article briefly presents the different trends of Biblical exegesis in Africa, while the second section deals with the different phases of intercultural exegesis.

\footnotetext{
${ }^{1}$ Jean-Claude Loba-Mkole, STD, PhD (Leuven), is lecturer at Hekima College and translation consultant with the United Bible Societies (Nairobi). Dr Loba-Mkole is a member of the International Advisory Board of HTS Theological Studies and a research associate of Prof Dr Jan G van der Watt, Department of New Testament at the Faculty of Theology, University of Pretoria.
} 


\section{TRENDS OF BIBLICAL EXEGESIS IN AFRICA}

The publication of Bible in Africa in 2000, which was the culmination of a project which started in 1995, has marked a major turning point for Biblical exegesis in Africa (West \& Dube 2000). This collection, with its thirty-nine essays, has not only shown the vitality of African Biblical scholarship, but also its particularity as "a variety of ways that link the Biblical text to the African context" (West \& Dube 2000:11). On the one hand, African Biblical scholarship emphasizes the "inclusiveness" with regard to the interpretative communities (scholars and non-scholars, male and female, rich and poor, clergy and lay people, Christian and non-Christian). On the other hand, this "inclusiveness" involves an extensive range of interpretative methods (historical critical studies, literary approaches and new hermeneutics including Bible translation theories and practices ...). In this variety of methods, inculturation or "theologies of being" and liberation or "theologies of bread" emerge as the main trends and constitute the "most persuasive paradigms" of African Biblical scholarship (West \& Dube 2000:34-35). In fact, the ultimate goal of African Biblical scholarship has been perceived as the willingness to be "related to life" (West \& Dube 2000:86) for the purpose of spiritual upliftment/deification (West \& Dube 2000:117) and social-transformation/ justice (West \& Dube 2000:496, 589, 629). From these interrelated perspectives and depending on a particular vision, Africans approach the Bible as an "unsafe book" (West \& Dube 2000:198), "a book of spiritual matters, not political or economic ones" (West \& Dube 2000:253-254), a book of "secret power" (West \& Dube 2000:339), a "political book" and a "supreme guide in Christian life" (West \& Dube 2000:385), a "powerful" book of the "Word of God", and/or a "book of devotion and norm of morality" (West \& Dube 2000:588-589). Besides, in a research survey conducted in Port Harcourt (Nigeria), Africans indicated that "love and salvation, followed by obedience, humility and peace" (West \& Dube 2000:588-589), were the central messages of the Bible.

In the field of New Testament interpretations, Biblical exegesis in Africa has taken a remarkable step forward with the publication of Interpreting the New Testament in Africa in 2001 (Getui, Maluleke \& Ukpong). ${ }^{2}$ This publication is the first result of the Hammanskraal Conference, which took place as a post-conference following the $54^{\text {th }}$ General Meeting of Studiorum Novi Testamenti Societas (SNTS), held at the University of Pretoria in August

\footnotetext{
${ }^{2}$ Other papers presented at the Hammanskraal Conference, especially those presented by New Testament scholars working as Translation Consultants with the United Bible Societies Conference were published by G L O R Yorke \& P M Renju (2004) (eds), Bible Translation and African Languages, Nairobi, Acton.
} 
1999. P Borgen, a former President of SNTS, described the Hammanskraal Conference as a "necessary and important step", which "set in sharp focus the basic question of the relationship between the Gospel and culture". He emphasized that the Gospel must be rooted in the culture of a people, which, theologically speaking refers to an incarnational aspect of the Christian message: "At the Hammanskraal Conference", he argues, there was an awareness not only of this encounter between the Gospel and a particular culture and a particular context, but also a realization of the universal perspective of the Gospel: There is a basic aspect of "givenness" of the Gospel of Jesus Christ in its interplay with culture and context" (Borgen in Getui, Maluleke \& Ukpong 2001:1). As a matter of fact, the majority of the Hammanskraal Conference papers focused on New Testament texts and African contexts. The latter rightly imply the promotion of an inclusive approach, which is open to all of those who are involved in the interpretation, translation and application of the Gospel (Getui, Maluleke \& Ukpong 2001:295).

Another result/outcome of the Hammanskraal Conference materialized in the form of the publication of Text and context, edited by Mugambi \& Smit in 2004. With this publication, African contextual hermeneutics found itself enhanced by some specific methodological approaches such as Reconstruction Hermeneutics, Rainbow Hermeneutics and the Hermeneutics of Ubuntu, to mention but a few included in the book Text and context. Apart from this book, other African Biblical hermeneutics are being investigated in terms of afro-centric, post-colonial, women's, semoya, storytelling, developmental hermeneutics, the hermeneutics of engagement, liberation, suspicion, resistance and many more. These hermeneutics still need more practical application, using specific New Testament texts or topics, and some scholars have indeed already embarked on this long journey. ${ }^{3}$ The following section attempts to show how this challenge is being taken up in the field of inculturation Biblical hermeneutic and intercultural exegesis or mediation.

\section{INCULTURATION BIBLICAL HERMENEUTICS}

\subsection{Ukpong and the parable of the shrewd manager (16:1-13)}

In an article published in 1996, Ukpong claims to have coined the term "inculturation Biblical hermeneutic" to designate an interpretation derived from

\footnotetext{
${ }^{3}$ A few examples are: Van Aarde (1994:575-596); Yorke (1995:1-13); Dube (1996:111-129); Dube in Sugirtharajah (1998:118-135); Njoroge \& Dube (2001:40-65); Speckman (2001); Punt, in Ukpong et al (eds) (2002:125-149).
} 
the methodology of inculturation theology. For him, the term "inculturation theology" does not refer to a specific theological discipline, but rather indicates a hermeneutical process in theologizing that cuts across all theological disciplines, including Biblical exegesis. In other words, "inculturation Biblical hermeneutic" is about the application of the inculturation paradigm to Biblical interpretation (Ukpong 1996). Other works too have attempted to relate Biblical religious cultures to African ones. ${ }^{4}$ The novelty of inculturation Biblical hermeneutic may very well reside in the fact that it explicitly seeks to interpret the Biblical text from the present socio-cultural perspectives and make them the subject of interpretation. Inculturation Biblical hermeneutic acknowledges the sacred status of the Bible and its normative value for Christian life. Nevertheless, taking the Bible's status as ancient literary text into account, this method uses insights from historical analysis and dynamically rereads the text against the contextual background of the present reader. By means of illustration, the section here below will expose the different steps of Ukpong's inculturation hermeneutic in the parable of the shrewd manager (16:1-13).

\subsubsection{The reader's socio-cultural context}

Most West Africans, whose background has been chosen as the subject of interpretation of this parable, are palm producers and cocoa farmers. They continue to live according to the worldview handed down to them by their traditional cultures, whereby material wealth is regarded as God's gift to the whole community and the exploitation of others is regarded as abnormal. However, with the influence of a money-oriented economy taking over that of bartering, farmers have fallen victim to middle class traders who buy farming produce at low cost from them and then sell the produce at very high prices. During harvest times, there might be an increase in oil prices, while the farmers cannot adjust the price of their produce accordingly. Yet, when oil prices go down, farmers have to reduce the prices of their harvest. The West African farmer constantly lives in such a context of exploitation, which is exacerbated by the weight of debts owed to the international community.

\subsubsection{Some interpretations of the parable}

Manson (1971) has interpreted the manager of the parable as a fraudulent, yet clever person. It is not the manager's fraudulent behaviour that is presented as an example to be followed, but his ingenious prudence in ensuring his future security. Based on Near Eastern customs, according to which a salesperson's salary was included in the price of the merchandise, Fitzmyer (1974a; 1974b) understands the manager's prudence to be found in

\footnotetext{
${ }^{4}$ See Ellingworth (1969); Dickson (1973:31-40); Naré (1986); Pungumbu (1992).
} 
the commission of the remuneration due to him. Topel (1975:216-227), in turn, argues that, like the father who, in the previous scene (15:11-32), had forgiven his prodigal son beyond all human measure, the manager too has forgiven his debtors beyond all expectation.

\subsubsection{Reading the text of the parable}

The parable of the shrewd manager appears in the section that deals with Jesus' journey from Galilee to Jerusalem ( 9:51-19:27). In this section, Luke develops three of the themes of discipleship, God's mercy and forgiveness, as he stresses that the kingdom of God is for the poor. The phrase "anthropos tis hen plousios" (a man who was rich) in Luke 16:1 links this parable to other Lukan episodes in which material wealth and riches are the object of Jesus' critiques (Lk9:57-62; 10: 25-37; 12: 13-21; 15:11-32; 16:1-13; 16:19-31; $18: 18-30 ; 19: 1-10 ; 19: 11-27)$. In its immediate context, this parable is sandwiched between two other parables, which explicitly mention the term "rich man". One of these parables criticizes the folly of hoarding material goods (Lk 12:13-21), while the other one exposes the eschatological punishment for the lack of generosity shown towards the poor (Lk 16:19-31). According to Ukpong, the mashal or the body of this parable consists of verses $1-8 a$, while verses $8 b-13$ forms the nimshalim or moral comments. Rather than praising the prudence of a clever manager, this parable conveys a severe critique of rich and unjust people through the characters of the rich man and his shrewd manager.

\subsubsection{Historical context of the parable}

The parable of the shrewd manager depicts a situation in which a rich man, probably the owner of a Galilean latifundium, entrusted his estate business to a manager. In the Greco-roman world of the first century AD, such a manager had the power to grant land loans repayable against harvest and with interest. $\mathrm{He}$ also had the power to liquidate debts and to grant reductions. From the text under discussion, it is clear that at the time of the manager's dismissal, the loans had not matured, since he had to call upon the borrowers to not pay what they had agreed upon earlier on, but to obtain new bonds for payment at maturity. After his dismissal, he knew that he would no longer have the authority, nor be in a position to collect his transaction fees when it was due. He then simply cancelled them, acting within his legitimate rights. This was not a matter of the manager forfeiting his fees or defrauding his master. The master nevertheless found his employee's behaviour as being "unjust". This is a reflection of how justice was understood within an exploitative economic system whereby whatever was to be paid by the poor, was viewed as a due to 
the beneficiary. The same exploitative system accounts for the accusation of "wasting" his master's goods, with the implication that the manager was not making enough profit for the master. Seen from the farmers' point of view, the reduction of their debts by the manager could have been regarded as an act of justice and solidarity as professed by the authentic worldview of Israel, whereby the rich people should share their wealth with the poor.

\subsubsection{Findings}

The lessons of the parable of the shrewd manager are of relevance not only to the farmer peasants of the first century Palestine, but also to those in contemporary West Africa. In both cases, the farmers are the victims of an exploitative economic system. In the parable the farmers were exploited by both the manager and the rich man. In a similar way middlemen and economic organizations in wealthy countries impoverish West African farmers today. Following his dismissal, the manager became a hero of justice on behalf of the exploited farmers; likewise Christians of West Africa are challenged to reverse the oppressive structures the middlemen traders and the International Monetary Fund's Economic Structural Adjustment Program (ESAP) impose on the poor.

\subsection{Matand and the council of Jerusalem (Acts 15:1-35)}

In 1998, Jean-Bosco Matand wrote an article on inculturation as it appears in Acts 15:1-35 and in Galatians 2:11-14, also using inculturation hermeneutic in his approach (Matand, in Kalonga 198:143-167). On the one hand, he distinguishes between exegetical reading and inculturation hermeneutic, the latter being regarded as a contextualized application of the former. On the other hand, he deals with what Scripture tells us about inculturation hermeneutic.

\subsubsection{Exegetical reading of Acts 15:1-35}

The episode of the council of Jerusalem is intercalated between the literary unit on the first mission of Barnabas and Paul to West Antioch (13:1-14:28) and that dealing with Paul and Silas' departure for further mission work ( 15:36-20:38). It clearly belongs to a narrative literary genre and, accordingly, its interpretation requires a narrative analysis. Applying narrative analysis, Matand divides this episode into three units: the starting point of the narrative (15:1-5), the development of the narrative (15:6-29) and the epilogue ( 15:30-35). The beginning of this narrative contrasts with the slight repose Paul and Barnabas had taken in the company of other disciples in Antioch (14:2728). However, they were soon disturbed by the teaching of some Judaizing 
evangelists who were insisting on the circumcision of all proselytes. As a result, a doctrinal dispute (stasis) developed, necessitating a quest for the truth (zêtêsis), and compelled Paul, Barnabas and others to take the matter (zêtêma) to the apostles in Jerusalem. Here, a debate developed, as some of the Pharisees defended the integrity of Mosaic Law. The deliberations of the Jerusalem meeting, constituting the second and central part of the narrative, include the speech of Peter (15:7-11); the account of Paul and Barnabas ( 15:12); the speech of James (15:13-21) and the "turning point" (15:22-29). Based on his own experience of God's wonders performed among the Gentiles, Peter concluded by asking the conference why God should be tested and the Gentiles subjugated to an unbearable yoke, given that both Jews and Gentiles have been saved through the grace of Jesus.

Thereafter, Paul and Barnabas gave full details (exêgeomal) of the signs and wonders (sêmeia kai terata) God had performed among the Gentiles through them. The Greek sêmeia kai terata is a translation of the Hebrew 'ôtôt ûmôptîm and evoke the idea of the mighty deeds God had done for the sake of Israel, particularly the liberation from Egypt. What is emphasized here is that God had done similar wonders for the Gentiles, just as Peter had argued. James' contribution, using a quotation from Scripture (Amos 9:11-12), reinforced Peter's argument and contained a concrete proposal. The universalistic perspective of God's salvation in Amos 9:12-12 is taken one step further through the Lukan addition of "anastrepsô" (return), introducing the idea of God's conversion to rebuild the house of David to accommodate both Israelites and Gentiles. Finally, James proposed that, because of the holiness of God, the converted Gentiles should abstain from idolatry and blood though, which is a core message of the Sabbath readings of Mosaic Law and which does not allow the worshipping of false gods and eating that which is reserved for God. As a result, the assembly of Jerusalem reached consensus and a turning point came about: Through the Holy Spirit the council decided not to insist on a literal observance of Mosaic Law by Gentiles as far as circumcision was concerned. However, Gentiles had to abide by the code of holiness, which excludes idolatry and profanation. This message was communicated to the Church of Antioch in a letter which was taken to them by an authorized delegation, comprising Paul and Barnabas, together with Judas, called Barnabas, and Silas, all considered as leading men among the brethren.

In the epilogue (Ac 15:30-35) the Pharisees' intransigence with regard to circumcision is no longer evident. They had been silenced by the arguments from Peter, Paul, Barnabas, and James, as well as by the decision taken by the whole assembly, guided by the Holy Spirit. Upon receiving the 
letter with the conference's decision, the brethren of the Church of Antioch which became the victim of some unauthorized teaching with Pharisaic bias, rejoiced. Judas and Silas strengthened this position through their exhortation in Antioch. After the latter had returned to Jerusalem, Paul and Barnabas, having been comforted by the Council of Jerusalem after their early doctrinal dispute and quest, remained in Antioch to teach and preach the Word.

\subsubsection{Findings}

Following the preceding exegetical analysis, some issues that are relevant to inculturation can be pointed out, namely the unity of the human race in Christ (i.e. Jews and Gentiles) and the recognition that Old Testament shows towards inculturation. The latter needs to be approached from a universalistic perspective as the quotation of Amos 9:11-12 in Acts 15:16-17 has shown. In that sense, one of the main inculturation goals is to unite all peoples and cultures under the same leader, the Christ and in the same Spirit as children of the same Father. Inculturation discourse would then imply preaching unity in faith and diversity in culture, rather than schism and uniformity. The Old Testament has always been a privileged topos for interpreting the will of God in New Testament writings, although the apostles were also heeding the voice of the Holy Spirit in their decision making process. Inculturation discourse should never minimize a revelation enshrined in the Old Testament and authenticated by the Holy Spirit.

\section{INTERCULTURAL EXEGESIS}

\subsection{Cilumba and the Nicodemus narrative (John 2:23-3:36)}

The concept of "intercultural exegesis" (interkuturelle Exegese) was also used and applied by C N A Cilumba in his doctoral thesis, published in 2001 (Cilumba 2001:3). He developed this method as a "logical consequence" of his involvement in a "school" of intercultural exegesis at the University of Bonn and his training in inculturation theology at the Catholic Faculties of Kinshasa. On an epistemological level, he grounds his intercultural exegesis on the philosophical hermeneutics of Hans-Georg Gadamer and Paul Ricoeur. In the process of understanding a text, both philosophers include three steps: precomprehension of the reader, a fusion of the reader's horizon and that of the text, and appropriation of the text by the reader (Cilumba 2001:13-16). Besides, the Bible itself is a living example of intercultural hermeneutic between the Word of God and human cultures.

\subsubsection{Literary structure}


The narrative of the encounter between Jesus and Nicodemus is found in a literary block constructed with antithetic and parallel features: an introduction (Jn 2:23-25 par 3:22-24), a direct speech or a dialogue (Jn 3:1-12 par 3:2530) and an indirect speech or monologue (Jn 3:13-21 par 3:31-36). Antithetic and parallel constructions appear not only at the level of the literary units, but also within each section. For example, verses 3 and 4 in the section of 3:1-12 are antithetic in the use of the verb gennèthenai (be born), as well as in the shift from the "I-you" style in John 3:1-12 (par 3:25-30) to the "he" style in John 3:13-21 (par 3:31-36). In the macro literary structure, John 3:1-21 is part of the section on Jesus' deeds (Jn 1:19-12:50), which follows after the prologue (Jn1:1-18), but is followed by the section of the signs (Jn 13:1:17:26) and that of the passion (Jn 18:1-20:31; 21). At least three main theories have been proposed to solve problems pertaining to the subdivision and incoherence of the Fourth Gospel. The triple source theory, attributed to Rudolf Bultmann, distinguishes the Sign/Miracle Source, Passion Source and the Discourse Source in the gospel of John. The evolution theory of Julius Wellhausen assumes that the gospel of John was written in different phases of extending and altering the first document, whose author remained anonymous. The theory of literary unity of the fourth gospel, initiated by Eugen Ruckstuhl, is based on the discernable stylistic features of a single author, who integrated material from both Johannine circles and the synoptic gospels.

\subsubsection{Tradition and redaction}

Some of the literal material in John 3:1-36 appears to have been taken from existing traditions, which include Old Testament theology, Christology of the early Church and Oriental wisdom/philosophy. An Old Testament element is found in John 3:14, re-actualizing the elevation of the serpent by Moses in the desert (Nm 21:4-9), while early Church Christology is embedded in John 3:35 , focusing on the motives of baptism and the kingdom of God. The text of John 3:29 make use of Eastern wisdom to express the excitement John the Baptist experienced in the presence of Jesus in terms of the joy a friend experiences in the presence of the bridegroom. As a matter of fact, the motives of sign, faith, Son of man, judgment, baptism and the use of Old Testament and Oriental wisdom confirm John 3's dependence on other traditions. As far as the history of the redaction is concerned, the units of John 2:23-25; 3:5, 19-21 and 31-36 have been identified as author's additions. John 2:23-25 was composed in order to introduce the narrative about Nicodemus (especially Jn33:1-18), whereas John 3:5 was inserted to emphasize how baptism forms a constitutive part of faith. John 3:19-21 was written as an anti- 
docetic interpolation. John 3:31-36 fits in as a concluding redactional comment on Nicodemus' narrative.

\subsubsection{Interpreting the text}

The interpretation of John 2:23-3:36 indicates the central importance of sign, faith and life in this section. Sign and faith are emphasized particularly in John 2:23-3:21, while life becomes a key element in John 3:22-36. John 2:23 introduces Jesus' ministry in Jerusalem and announces the link between sign and faith, which would be further elaborated upon in the dialogue between Jesus and Nicodemus. This dialogue comprises three sections, namely John 3:1-3; 3:4-8; and 3:9-21. In John 3:1-3, the author opposes a Jewish teacher (Nicodemus) and a teacher from God (Jesus). In John 3:4-8, natural birth is contrasted with the heavenly or spiritual birth from, which is received through a combination of water (natural sign) and the Spirit (divine reality). John 3:921 explains how a person who "understands" the sign that leads to Christ, will have eternal life. The last section (Jn 3:22-36) uses a testimony setting of John the Baptist to allude to the importance of the trilogy sign-faith-life.

\subsubsection{Life, faith and sign in a Congolese context}

In the DRC, the concept of life is considered to have a dynamic and holistic meaning. It originates from God the creator and it does not end with death. It needs to be wholly experienced in harmony with God, the ancestors, the cosmos and with people. The concept of life already includes faith, since the former is seen as a gift from God the creator. This idea was corroborated by the first missionaries, although their emphasis was more on the salvation of souls, than it was on the upliftment of the whole person. In the present Congolese context, Christianity is significantly marked by the integration of cultural dimensions in the light of a better understanding of the implications of Christ's incarnation. Sign is also related to God. Although some traditional healers (Nganga in the Linguala language) may perform some miraculous feats, the ultimate origin of miracles is attributed to God as the only one who can perform things that are impossible to human beings.

\subsubsection{Findings}

The Johannine gospel and Congolese Christians understand human life as participation in the eternal life of God through the person and paradigm of Jesus-Christ. In the gospel of John and in Congolese Churches, faith is theochristocentric and it involves individual and communal dimensions. In John, the miracle serves as a springboard for the Christological revelation, and it is often accompanied by a reprimand and human satisfaction. In the DRC the 
aspect of reprimand is almost absent, as the emphasis tends to be rather placed on human satisfaction, even at the expense of the faith in Christ. The link between Christological and anthropological dimensions needs to be reinforced in the DRC.

\subsection{Manus and the healing of the leaper (Mk 1:40-45) $)^{5}$}

The model of Manus (2003:40-41) closely follows the procedure proposed by Ukpong (1996:190-191). He begins the interpretation of Mark 1:40-45 with the question: "What can an intercultural exposition of the miracle story of the leper offer the African Church and her people?" He answers:

If we agree with Justin Ukpong and other African scholars that intercultural hermeneutics is an 'academic reading of the Bible that is informed by the perspectives and concerns of ordinary readers and ordinary readings, then the ordinary African peoples' sociocultural contexts where the HIV/AIDS pandemic unabatedly prevails as a killer-disease is apt to be made the subject of a sympathetic interpretation of the healing of the Leper in Mk 1:40-45.

(Manus 2003:139)

\subsubsection{Current context}

According to agencies such as UNAIDS, 27 million out of the 36 million people infected with HIV/AIDS worldwide, live in Africa. In certain African countries, more than $10 \%$ of the population suffer from HIV/AIDS (Botswana: $35.8 \%$, Swaziland: 25.25\%, Zimbabwe: 25.6\%; Lesotho: $23.57 \%$, Zambia: $19.95 \%$, South Africa: 19.94\%, Namibia: 19.54\%, Malawi: 15.96\%, Kenya: 13.95\%, Central African Republic: 13.84, Mozambique: 13.22\%, Burundi: $11.32 \%$, Djibouti: $11.75 \%$, Rwanda: 11.21 ; the Ivory Coast: $10.76 \%$, Ethiopia: $10.63 \%$ ) (Manus 2003:141 \& Wendland \& Loba-Mkole 2004:84). African Churches are not unaffected by the challenges posed by HIV/AIDS. For Manus, a reading of Mark 1:40-45 can equip Christians with a theology that can re-condition the faithful to engage in intensive prayer and "appeal" to the Lord Jesus as Healer

\footnotetext{
${ }^{5}$ Interestingly, Manus uses inculturation, liberation and reconstruction approaches as variants of intercultural hermeneutics. A few examples are mentioned in this regard: Manus applies an inculturation approach to Paul's speech at the Areopagus (Acts 17:22-34), in analyzing the text and the context of the speech on the one hand, while exposing an lgbo version of the same speech on the other hand. He displays a liberation approach in examining the issue of Scriptures and women, comparing Yoruba sacred narratives to some New Testament texts (1 Tm 2:11-14; $1 \mathrm{Pt} 3: 7)$. Finally, he presents a reconstructive re-reading of the cleansing of the temple (Mk 11:15-19), providing the analysis of the text and the socio-historical context of the story before interpreting it through the paradigm of "Jesus the reconstructor".
} 
of all evils and terminal illness to intervene decisively in our diseased world (Manus 2003:142).

\subsubsection{Socio-historical context}

In Jewish Palestine, contagious diseases like leprosy were quite rampant, and most physical ailments were seen as God's punishment for one's sins or those of the parents. It was the prerogative of a priest to declare someone leprous and therefore as "impure" and as an "outcast", or to rehabilitate the person after his/her healing and purification (Mulholland 1999:30). In the Markan story, the Leper broke the stigma of the day when he appeared in public and interacted with Jesus, contrary to the social rule in force: "Infected persons were required by the Mosaic Law to live in seclusion and to shout 'Unclean, unclean' (Lv 13:45-46) as a warning to anyone who approached them" (Mulholland 1999:30). This leper, on the contrary, is the one who dared to approach Jesus and implored him to intervene in a desperate situation. Besides, the leper appeared from nowhere! This episode, which in some respects seems historically improbable, might fit into Markan redaction skills used to describe a powerful feature of Jesus and to emphasize his popularity, in view of his confrontations with religious authorities that lie ahead (2:1-3:6).

\subsubsection{Synoptic analysis}

Mark (1:40-45) and Luke (5:12-16) do not have a geographical placement, but they do report that Jesus had retired to a quiet place. According to Matthew $(8: 1-4)$ this incident had taken place when Jesus had come down from the mountain. In Mark and Luke, the healed man became an unauthorized herald who, ironically, and notwithstanding a formal prohibition, attracted many people to seek Jesus. Matthew does not mention the public impact of the event, while Mark humanizes Jesus in his emotions (moved with pity) and Matthew and Luke, on the other hand spiritualize him and his actions. However, for all three of the synoptic evangelists, Jesus is the compassionate healer and the Son of God who brings divine mercy in order to re-integrate the outcast into the community of the living.

\subsubsection{Findings}

With so many Africans being either infected or affected by HIV/AIDS, the pandemic has a devastating effect on many families and communities in Africa. In the narrative about the encounter between Jesus and the leper, Mark shows how Jesus, full of compassion, touched the leper and healed him. Jesus' willingness and action to cure the leper instantly compels us to hope 
for a quick cure for and healing of HIV/AIDS. This hope can be actualized through intensive prayers and moral support for the sick.

\title{
4.3 Loba-Mkole and Jesus' exaltation narratives ( 22:69 and Ac 7:56)
}

I understand intercultural exegesis as a constructive dialogue between an original Biblical culture and that of a receptive audience, taking cultures of Christian traditions into account as well (Loba-Mkole 2005:x, 1-2, 29). Here, the epistemological privilege is not only given to the receptive audience (contra Ukpong [Dietrich \& Luz 2002:10, 58, 69]), but is equally shared by the three sets of cultures involved in this dialogue. A unique epistemological privilege is granted to the original Biblical cultures because of their canonicity, while the cultures of Christian traditions benefit from a particular epistemological privilege due to their elderliness, and the current target cultures are entitled to a peculiar epistemological privilege because they are currently living in blood and flesh. It would appear to me as if this concept of intercultural exegesis is best conveyed by the expression "intercultural mediation", since the dialogical process under consideration involves not only literary works, but also artistic symbols and human heroes (Dietrich \& Luz 2002:2) all of which ensure the transmission of the Gospel from one culture to the other. In Africa, the epistemological value of intercultural mediation needs to be measured against African worldviews that value the promotion of life, as well as against authentic messages of Jesus and those of Church traditions.

\subsubsection{Luke 22:69 and Acts 7:56 seen in a current culture}

The results of research on the relationship between Luke 22:69 and Acts 7:56 have been well summarized by Dillon:

\begin{abstract}
Remarkable for both this "standing" posture and for being the very rare Son-of-Man saying on other than Jesus' lips, this word of the martyr is likely Luke's variation on Luke 22:69 in further elaboration of v 55 (so Conzelmann, Schneider, Weiser, Sabbe, Mussner). "Standing" may bespeak the Lord's welcome to his martyr in an individualized parousia (Barret), or his intercession for the confessor true to Luke 12:8 (Schneider), or his exercise of judgment against recusant Jewry (Pesch); or, least plausibly, it could be a "meaningless" variation upon the risen One's sitting at God's right hand (2:33-35; Mussner, Sabbe).
\end{abstract}

(Dillon, in Brown 1990:742)

However, the semantic content of Son of man remains problematic, as the majority of New Testament scholars interpret it as a messianic title 
appropriated to Jesus because he is the Messiah, the Son of God. In Congolese oral literature, as it is conveyed by musicians, the Lingala expression "mwana ya moto" (son of man/daughter of man) refers to a human being, mainly with generic and circumlocutional connotations. In some of the songs by Koffi Olomide, Madilu Système and others, the phrase "ngai mwana ya moto" (I, the son of man) or "mwana ya moto" (son of man) refers to the singer himself, as he refers to his human nature, dignity or weakness. In the song "La beauté d'une femme" (the beauty of a woman), the female singer, Mbilia Bel, treats her co-spouse female rivalas "mwana ya moto lokola ngai" (daughter of man like me) in contrast with "mwana ya Nzambe" (daughter of God), who justifiably would have been proud of her extraordinary nature and beauty. In certain cases, for example in Mungua's novel, "son of man" is used as an informal name alongside the Lingala "mwana ya mama" (son of mother) or the "son of woman". In this novel, the main character calls himself son of woman to underline his solidarity with humankind, and especially his connection with women (Mungua 1988:1, 9). Generally speaking, one could refer to all human beings, especially to males, as sons of men. For the ordinary Christian in Africa, Son of man in Luke 22:69 and in Acts 7:56 would refer to Jesus, by virtue of his human nature or his solidarity with human beings. Furthermore, the majority of sons of men in Africa are subjected to abject poverty, which gives rise to many moral vices and psychophysical diseases. Can the Son of man in Luke-Acts and the sons of men in Africa have anything in common?

\subsubsection{A contrastive linguistic analysis of Luke 22:69 and Acts 7:56}

These texts are found in the literary context of a trial, especially that of a protagonist. The most striking similarity between Luke 22:69 and Acts 7:56 relates to the lexical use of the phrase "Son of man". In both cases, "Son of man" is used by the protagonist in the particular scene, namely Jesus in Luke 22:69 and Stephen in Acts 7:56. On a grammatical level, there is a certain dissimilarity, since "Son of man" in Luke 22:69 is the subject of the verb estai kathèmenos (will be seated), while in Acts 7:56 it appears as a second complement of object of the verb theôrô (I see). While shifting from Luke 22:69, Acts 7:56 echoes Mk 14:62 par Mt 26:64 in terms of its grammatical construction, insofar as in these cases "Son of man" is the object of a verb of sight (cf opsesthe in Mk 14:62 and Mt 26:64; and theôrô in Ac 7:56). In terms of content, "Son of man" in Mark 14:62 par Matthew 26:64 and Luke 22:69, is used in a circumlocutional sense, indicating a self-reference by the speaker Jesus, which is not the case in Acts 7:56. The non-circumlocutional use of "Son of man" in Acts 7:56 seems to correspond with Revelation 1:13 and 
14:14. The announcement about seeing the "Son of man" sharing God's lordship in Mark 14:62 is fulfilled in the visions of Acts 7:56, Revelation 1:13 and 14:14-16, although Son of man in Revelation(cf Dn 7:13) is not affected by the double determinative (definite article ho = "the" and the genitive tou =) "of the", as is in the case in John 5:27. Yet, despite this anarthrous use of "Son of man", ${ }^{6}$ which may suggest its non-messianic understanding, it still refers to Jesus who was nevertheless confessed as Messiah and Son of God through these two titles (i.e. Messiah and Son of God). In a nutshell, a contrastive analysis shows that Luke 22:69 emphasizes the exaltation of "Son of man" in heaven, while Acts 7:56 brings this exaltation down to earth, to a concrete disciple, who had had the vision of the "Son of man's" exaltation (see also Rv $1: 13 ; 14: 14)$. The contrast between the seating posture of the Son of man ( 22:29; cf Rv 14:14) and the standing one (Ac 7:56) may not make a big difference as far as his heavenly exaltation is concerned. What matters more, is the impact the visions have on earth. Stephen and John, who have received these visions, surely would have been equally respected and honoured in their communities, irrespective of the position in which the "Son of man" may have been perceived in heaven. These visions also increased the trust put in Stephen and John as mediators between the Gospel of Jesus and other disciples. Similarly, certain leaders in African Churches gain more esteem as result of their visions and Gospel mediations.

\subsubsection{Historical context}

The literary contexts within which the trials in Luke 22 and Acts 7:56 are recorded, may be seen as a genuine effort to document some of the events pertaining to the death of Jesus and the persecution of his disciples. The impression may be that Jesus had been killed as a prophet of God, but not as the so-called divinely "Son of man", while Stephen met a similar fate for bearing witness to the name of Jesus during a persecution of Christians. Moreover, in the context of Luke 22:69 Jesus had experienced a "status degradation ritual" and in that of Acts 7:56 Stephen underwent a similar ritual in which the honour of a person is fatally undermined (Malina \& Rohrbaugh 1992:271). Ironically, in terms of his eschatological exaltation and by expressing his solidarity with humankind through the phrase Son of man, Jesus was honoured in the eyes of God and that of Christians. For his part, Stephen was certainly honoured, not only for his vision, but also for his

\footnotetext{
${ }^{6}$ If the double anarthrousness of Christou ("of Christ") in Mark 1:1; 9:41, and that of Son of God in 15:39, stresses the quality of Jesus' divine sonship (Gundry 1993:951), an analogue argument can be used to affirm that the anarthrous use of "Son of man" in John 5:27, Revelation 1:13, 14:14 underscores the humanness of Jesus, without denying his divinity. Similar ideas are developed by Wink (2001).
} 
courage to confess Jesus before men at the expense of his life (cf 12:8-9 par Mt 10:32 and Mk 8:38).

\subsubsection{Findings}

By the phrase "Son of man" the author of Luke 22:69 and Acts 7:56 has underlined not only Jesus' human nature, but also his solidarity with humankind, especially in a context of suffering and humiliation. This very humiliation has been turned into a motive of honour, not only pertaining to Jesus, but also to the disciples who were persecuted because of Him. In Luke 22:69, Jesus can be seen as the intercultural mediator between God's realm and the world, while in Acts 7:56 Stephen plays a similar role between Jesus and an early Christian community. Luke 22:69 and Acts 7:56 also show how Jesus and his first disciples have experienced the suffering and persecution inflicted upon the sons and daughters of men/sons and daughters of women in current Africa. By virtue of solidarity, they are also entitled to share in the Honour of the Son of God, who associated himself with all human beings by his self-given name of Son of man or his "subjective identity". They are also invited to become intercultural mediators between Jesus' Gospel and their respective communities.

\section{CONCLUSION}

Since the introduction of inculturation Biblical hermeneutic by $\mathrm{J} S \mathrm{Skpong}$ in 1996, intercultural Biblical exegesis has become a reality in Africa. From this perspective, an African context and the African people are not merely regarded as a field to apply "exegetical" conclusions, but they stand as the subject of interpretation, equipped with genuine epistemological privilege. Whereas Matand and Cilumba still maintain a distance between the "exegesis" of the text and its contextualization (or hermeneutic), studies by Manus and Loba-Mkole support Ukpong's view in integrating African context/people as one of active components of intercultural hermeneutic/exegesis/mediation. This diversity of opinion can, however, be regarded as a healthy tension between the practitioners of intercultural Biblical dialogue. All the case studies presented in this article prove the vitality of this approach, where a "classical exegesis" and a "cultural analysis of a present situation" constitute integral parts of the entire process of interpreting Scripture.

\section{Works consulted}

Brown, $\mathrm{R}$ et al 1990. The New Jerome Biblical Commentary. New York: Printice-Hall. 
Cilumba, C N A 2001. Wunder, Glaube und Leben bei Johannes: Eine exegetischhermeneutische Studie am Beispiel von Joh 3 im Hinblick auf die Inkulturationsaufgabe. Bonn: Borengässer.

Dickson, K A 1973. The Old Testament and African Theology. Ghana Bulletin of Theology 4, 31-40.

Dietrich, W \& Luz, U (eds) 2002. The Bible in a world context: An experiment in contextual hermeneutics. Grand Rapids, MI: Eerdmans.

Dube, M W 1996. Readings of Semoya: Batwana women's interpretations of Matt 15:21-28. Semeia 73, 111-129.

Ellingworth, P (ed) 1969. Biblical rand African b. London: Lutterworth.

Fitzmyer, J (ed) 1974a. Essays on the Semitic background of the New Testament. Atlanta, GA: Scholars Press.

Fitzmyer, J 1974b. The Gospel according to Luke x-xxiv. New York: Doubleday.

Getui, M N, Maluleke, T \& Ukpong, J S (eds) 2001. Interpreting the New Testament in Africa. Nairobi: Acton.

Gundry, R H 1993. Mark: A commentary on his apology for the cross. Michigan, MI: Eerdmans.

Loba-Mkole, J-C 2005. Triple heritage: Gospels in intercultural mediations. Kinshasa: Ceril.

Malina, B J \& Rohrbaugh, R L 1992. Social-science commentary on the SGospels. Minneapolis, MN: Fortress.

Manson, T W 1971. The sayings of Jesus as recorded in the Gospel according to St Matthew and St Luke. London: SCM.

Manus, U C 2003. Intercultural hermeneutics in Africa: Methods and approaches. Nairobi: Acton.

Matand, B J 1998. L'hermeneutique de l'inculturation dans Ac 15 et Ga 2, 11-14, in J Kalonga (dir), Inculturation de la vie consacrée en Afrique à l'aube du troisième millénaire: Acte du cinquième colloque international, 143-167. Kinshasa, Carmel Afrique.

Mugambi, J N K \& Smit, J A (eds) 2004. Text and context in New Testament hermeneutics. Nairobi: Acton.

Mulholland, D M 1999. Mark's story of Jesus: Messiah for all nations. Oregon: Wipf \& Stock.

Mungua, C 1988. Son of woman. Nairobi: Spear Books.

Naré, L 1986. Proverbes salomoniens et proverbs mossi: Etude comparative à partir d'une nouvelle analyse de Pr 25-29. New York: Peter Lang.

Njoroge, N J \& Dube, M W (eds) 2001. Talitha Cum!: Theologies of African women. Pietermaritzburg: Cluster.

Pungumbu, L 1992. L'intervention sociale d'Amos: Une contribution à l'étude de la mission prophétique en Afrique aujourd'hui. Diss: Bruxelles.

Speckman, M T 2001. The Bible and human development in Africa. Nairobi: Acton.

Sugirtharajah, R S 1998. The postcolonial Bible. Sheffield: Academic Press.

Topel, L J 1975. On the injustice of the unjust steward: Luke 16:1-13. CBQ 37, 216227.

Ukpong, J S 1996. The parable of the shrewd manager (16:1-13): An essay in the intercultural Biblical hermeneutic. Semeia 73, 189-210.

Ukpong, J S et al (eds) 2002. The Bible in the global village: Cape Town Atlanta, GA: Scholars Press. 
Van Aarde, A 1994. The epistemic status of the New Testament and the emancipatory living of the historical Jesus in engaged hermeneutics. Neotestamentica 28(22), 575-596.

Wendland, E R \& Loba-Mkole, J-C (eds) 2004. Biblical texts and African audiences. Nairobi: Acton.

West, G O \& Dube, M W (eds) 2000. The Bible in Africa: Transactions, trajectories, and trends. Leiden: Brill.

Wink, W 2001. The human being: Jesus and the enigma of the Son of man. Minneapolis, MN: Fortress.

Yorke, G L O R 1995. Biblical hermeneutics: An Afrocentric approach. JRT 52, 1-13.

Yorke, G L O R \& Renju, P M (eds) 2004. Bible translation and African languages. Nairobi: Acton. 